\title{
Healing the nations
}

\author{
Karl Dortzbach ${ }^{1}$ \\ (University of Pretoria)
}

\section{ABSTRACT}

\section{Healing the nations}

This article gives the motivations, methodology and some results of a study done in Christian healing interventions in African contexts of stress and violence. Healing in community has been viewed through the prism of "shalom". Shalom occurs when people who are in a right relationship with God and each other enjoy and share together the resources of the earth in ways that show Christ is Lord of all creation. Charts are given showing the various kinds of community needs, ways to intervene, and some indications of ways to evaluate the interventions.

\section{A BROKEN WORLD IN NEED OF HEALING}

In an African world that is broken and burdened by wars, failed leadership, economic inadequacy, and imperialism both historic and present, the needs for healing are overwhelming. Consider the need for bringing comfort to a mother whose young son was killed because of an ethnic clash. Or the need to care for a young girl whose mother died from HIV transmitted through her father. Or the need to advise a young woman who was raped by a pillaging soldier and is now rejected by her own people because she gave birth to a "snake". What heals these deep wounds in individuals and in society?

Neither traditional healing methods nor western/modern healing methods seem to work. In the past, the community might plant a tree that has always symbolized peace and grew to speak of the curses and blessings of breaking a peace covenant. (A present project carried out in Kenya is reviving this practice. Their findings are journaled in the monthly publication, Kocha produced by Community Peace Museums Programme, PO Box 14894, Nairobi, Kenya). But a boy urinating at the root of a tree does not recognize the tree as a "peace tree", he only knows the pressing need of his bladder. He is likely to be one of the $50 \%$ of Kenyan boys who

1 The article is based on the author's PhD thesis in the Department of Science of Religion and Missiology (2002). His promoter was Prof J J Kritzinger. 
could not go to secondary school because of the lack of space (Daily Nation, Feb 10, 2002:1). He knows not why his grandfathers planted the tree, nor does he understand drugs useful for his bladder infection. The cock that was sacrificed for the spirits and left on the road nearby as a means of breaking the curse of drought is likely to be snatched and eaten by his gnawing spirit of hunger. He is a child that understands neither the past nor the modern world.

Our despair grows as we listen to that cock crow on BBC's Network Africa news programme. Someone in an interview reprimands the UNHCR and the world (meaning western world) for ignoring the plight of his country. More should be done, more food, more medicines, and more education. The "world" experts are mostly in their twenties or thirties who have studied at prestigious universities and speak more than one language. They plan programmes for shelter and food security. Displaced children are moved through intricate channels to find family. The "providers" are driven in fleets of big white airconditioned $4 \mathrm{X} 4 \mathrm{~s}$ and chatter on their mobile emergency radios. Prices on "adequate housing" soar and local businessmen's pockets bulge. For a brief year or two or three there are clinics and medicines and programs and people with money. Then, like a body on the rainforest floor, African realities creep back. The place of frenzied activity is left silent, with only the dark holes of a skull asking, "Healed?"

\section{NARRATIVE THEOLOGY AND HEALING THE BROKEN- NESS}

For centuries Christianity has provided answers to broken people and societies. Some would question whether those ecclesiastical answers are appropriate. Others would want to return to African religious traditions or find some newer Christian answer. Everywhere the myth seems to exist that "the way I see things" is the only way things really are. In the language of healing this amounts to saying "your healing has occurred when I say so". Universalizing this kind of formula for healing is little more than prattle on a two-way radio.

It is long overdue to release the myths of the past and the present, even though those myths will continue to live among us. In the place of clutching our myths, we must begin to do narrative theology. Whether we are missionaries or millionaire businessmen, African academicians or healing practitioners, we all do a kind of narrative theology. We all 
practice what we believe and talk about what we practice in the context of what we believe. Let us liken theology to a mango tree.

Like the mango tree that is planted in one generation for the next, good narrative theology today will follow biblical truth (that which was planted generations ago), but it will bear more mature and different fruit, or theological application. The narrative theology of healing, for example, is in fact is a great deal like the mango. It is possible to expect true healing for this wounded generation. But for the healing to take place it may be necessary to cut away the tightly held understanding ("sweet fruit") of what our theology of healing is. That would get us back to a basic core or seed of theology. The mango suggests several options for us. First, we can eat the fruit and throw away the seed. Second, we can burry the entire mango in the soil. Or third, we can eat the fruit and bury the seed for a future generation.

Some regard the Bible as simply the sweetness of fruit around a useless seed, they eat the fruit and burn the seed. It is a bit like saying that whatever people practice and think about God (the sweet fruit), is true about God (Healey and Donald Sybertz 1996:48) and there is nothing more. Others regard narrative theology as something sacred, all of which must be put into contemporary soil to grow up into a future tree. A bit like saying that whatever the Bible says must be seen in life today.

In reality the fruit may be eaten, but it is the seed that grows into a tree and simply needs to be planted in fertile soil - which is to say that the principles of the Bible both guided people of old and will guide people today (Alexander and Rosner 2000) but the way they live out Biblical truth will change greatly over time and between cultures.

Narrative theology in the Bible was theology in practice. It was how God's people understood and obeyed His words. Our narrative theology should begin in the same place and instruct us today. But if we are unaware of the strong influence of our cultural times, we are more likely to start where we are and work backward so as to seemingly instruct God as to how He should work. The desire for healing the immense pain and dysfunction in the world around us can drive us to that short cut.

Two examples will serve to illustrate the point. The first comes from the seventeenth century in Europe, where glaciers were advancing into the houses and crops of people. The church bishops were called upon to "exorcise the Spirits" of the mountains of ice. One bishop's exorcism 
seemed effective, and he was called back. Exorcisms of this type became a ritual, and this kind of practice continued for centuries.

Six processions of the reliquaries of St Genevieve and St Marcel took place in Paris during the eighteenth century, after being authorized by Parliament: four times to obtain rain $(1603,1611,1615$, 1694) and twice to make it stop (1625 and 1675). In many vinegrowing areas - for example around Paris - the custom was to take the Blessed Sacrament into the vines to protect them from worms and insect pests. The use of exorcisms used to be general: they drove away evil and misfortune. G Le Bras has counted 120 documents in the archives of Doubs from the years of 1729 to 1762 containing requests to the archbishop for formulae for exorcising insects and rats (Delumeau 1998: 41).

In Europe the belief was held and practiced, therefore, that Christianity had incantational powers over everyday parts of life that brought suffering (Thomas 1971:62). This was sixteen centuries after Christianity came to Europe. It is questionable (so we might observe today) that the bishops' words either moved the mountains of ice or chased away the rats.

But this type of magico-religious cultural expectation is no different in Africa in the twenty-first century, the second example. Here a "Spiritfilled" church-planter goes to a small social disease-infested town in Kenya and calls a handful of faithful to fast and shout incantations of strange sounds that form no known language. A local witch is then identified, who has brought the misfortune on the town, and "cast out". The town is proclaimed as "transformed". The film "Transformations", produced by Sentinel Group has been shown widely in recent years as a demonstration of "researched" places in the world where Christianity has brought total change in situations of misery (Sentinel Group 2001).

As the sixteenth and seventeenth century bishops' incantations questionably made any difference in the mountains of ice, so the incantations made in Kiambu, Kenya are equally questionable in whether they made a difference in the number of town bars. However, there is a spiritual reality that does bind these situations and others into a common Christian theology. Christianity impacts the lives and beliefs of people. Those people make changes. The change produced may be an industrial change that impacts the glacier, or a sanitation change that impacts the rats, or a 
social change that impacts alcohol consumption. The first change is a physical change, the second may be a corporate volitional change, and the third a social change. All three types of changes help alleviate suffering. All three changes may be spiritual changes, because they involve the human spirit, by the presence of the Divine Spirit, working from the inside out. Christianity is an inside-out religion, even if it is often practiced in outside-in ways. Kraybill expresses this in terms of the "upside down Kingdom" that focuses on relationships and not merely words (Kraybill $1990: 20,21)$. It is not the power of incantation, but the power of incarnation that brings transformation and community healing. This is narrative theology which both speaks truth and lives it.

What are those inside-out changes that bring healing both to individuals and to communities? While we may not fully grasp the human process of understanding, socializing, choosing, and emotional bonding so as to clearly articulate the forces of change, it is possible to recognize that forces of change work together to create a whole that is more than the sum of the parts. Healing in that sense is synergistic. To understand it requires a holistic view of the world and mankind.

\section{HOLISTIC HEALING NEEDED}

Holism is neither a new idea nor practice in Christianity. How we live out the entirety of our lives is in fact the narration of our real theology. The Protestant reformation in many ways reacted against the narrow and seemingly superstitious views and practices of the Catholic Church. Seventeenth century Protestant theologians were horrified at the idea of offering the sacrament of the Lord's Supper to grape bushes with the expectation of a good harvest. But the Anglican traditions did read gospels to cornfields believing that God would bestow some strength to the corn and the air that people needed (Thomas 1971:62). Those who followed the more rigorous ideas of the protestant reformers rejected the magical powers and supernatural sanctions that pervaded the church in the Middle Ages (Thomas 1971:68). It is ironical that Wesley with other "enthusiasts" set up dispensaries in the eighteenth century to "heal" all sorts of illnesses and then felt the wrath of the established Anglican Church (MacDonald 1982:117) because of the popularity of such practice. The "strangeness", as it were, of his practices has led some to feel that it "would not be difficult to picture Methodism as a kind of preview of Pentecostalism with a dash of Christian Science thrown in" (Rack 1982:138). 
For centuries in European Christianity, theologians taught and believed in the importance of holistic thinking and living. It was finally formulated into the Westminster catechism question and answer, "What is the chief end of man? To glorify and enjoy him forever". So was spoken a worldview that later would be called the protestant work ethic. What we, however, need to observe is the parallel between the changes in a holistic European worldview over generations, and the changes in African worldview today. The place of magic or "spirituality" was very much the same in pre-reformation Europe as it is today in Africa. What happens when a "modern" worldview rubs against the more traditional magicospiritual world? Not surprisingly we find belief practices that appear in Africa today which resemble pre-reformation Europe. The entire range of beliefs (magical to rational) contains permutations of holistic thinking about life. Consider the interest in holistic thinking as it relates to modern health care.

The 1978 health conference in Russia at Alma Ata began a movement toward "Health for all by 2000". It enabled a focus on community-based health, because it changed the health priority from secondary health measures to primary health (Ewert 1984:5). The new global priority was not on what could be done in a sophisticated hospital, but upon what people could do for themselves. This shift helped lower infant mortality and improve many aspects of health. In spite of so much global effort to bring health care to the two-thirds world, western style health care does not bring much healing.

Only a few years before 1978, disaster response increasingly drew global attention and gave birth to the rise of non-governmental relief and development agencies. Some agencies delivered a "product" of improved agricultural production for the development of people and their communities. Typically this would be expressed as a holistic ministry of the church, if the agency were a Christian agency. A model goal would be "To improve the quality of life of farming families and to minister holistically to men and women" (Batchelor 1993:192). The worldview of the west was constantly intruding, so that the measurement of the success of the "quality of life" came to be demonstrated by "...quarterly reports, with photographs, showing the numbers of farmers who had been reached, numbers of men and women who had learned to read and write, numbers who came under the sound of the gospel and so on" (Batchelor 1993:29). 
Recognizing this kind of cultural myopia, Christian development agencies increasingly have attempted to define and measure a "holistic" approach of ministry. One of those attempts is provided by Dr John Steward as a workshop entitled "Biblical holism: Where God, People and Deeds Connect". Produced by World Vision Australia in 1994, it arose from a seed of thought provided by Christopher Wright, and was refined by Steward and many of his Asian colleagues in seventeen years of Christian development work. This thought paradigm uses a triangle as a reference for the relationships between God, people, and actions (Steward 1994).

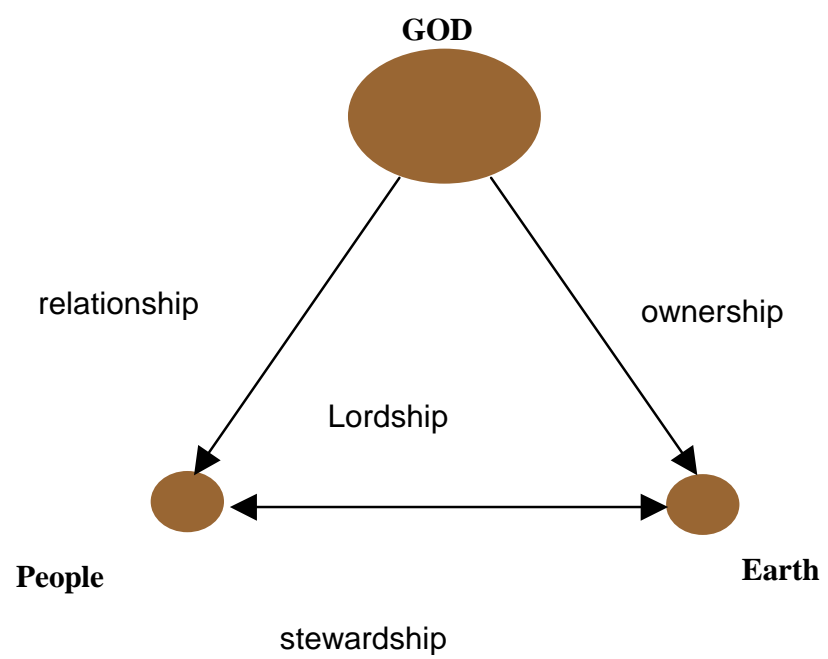

The primary connection between God and people is defined as one of relationship; the connection between people and the earth is one of stewardship; and the connection between God and the earth is one of ownership. The integration of these is seen as "Lordship" (Steward 1994:11). Thus a biblical theological framework is provided that sees the "people" as not just individuals, but as the people of God in Old Testament times, New Testament times and today. The earth is not just the land of Canaan, but also all that God promises to His people.

If this paradigm is followed one step further, so that the nature of the connections are explored, we may understand that the primary relationship between God and His people is one of love. The primary aspect of stewardship is one of choice or volition, and the primary aspect of ownership that the Bible speaks about is understanding. 


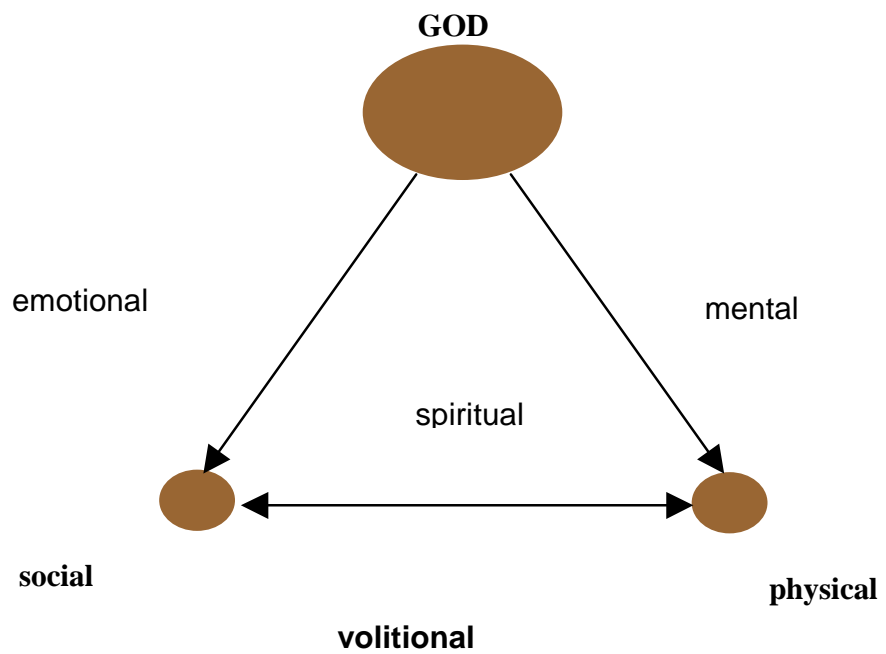

Luke 10:27, "Love the Lord your God with all your heart and with all your soul and with all your strength and with all your mind"; and, "Love your neighbor as yourself" is perhaps the clearest text that spells out the breadth of meaning of Shalom. Heart is the "the centre and seat of spiritual life, the fountain and seat of the thoughts, passions, desires, appetites, affections, purposes, endeavours" or simply the volition. Soul is "the seat of the feelings, desires, affections, aversions", or emotions. Strength or ""ability, force, strength, might", is all that is physical. Mind is the understanding and mental capacity. Neighbour is "any other human, irrespective of race or religion, with whom we live", and is the reflection of our social dimension (definitions from Strong 1995). Taken together, these meanings encompass the biblical understanding of shalom, salvation, and health. The Hebrew ruler who received Jesus' answer had asked the question "What must I do to inherit eternal life?" The answer was that eternal life, or salvation, was the result of living in shalom - being emotionally, socially, volitionally, physically and mentally in right relationships with God, man and the earth.

If we return to the analogy of the mango tree, we may see this biblical paradigm as the seed that has various cultural "fruits" around it. We may identify key biblical holistic values: a person could be understood as healthy or unhealthy in terms of the emotional, social, volitional, physical, and mental aspects. But the key question still remains, how are these attributes practiced in the healing process in an African community? What exactly is the "fruit" around the biblical truth?

In order to understand that it is necessary to listen to the narration of contemporary African church leaders as they reflect on how the Bible is lived and practiced in the healing process in their lives and communities. Listening to their stories and evaluations is a fundamentally emic task. It 
begins with stories that African church leaders themselves see as stories where healing has taken place.

There is a natural tendancy to want to tell the story of our own successes. Helpful stories that should be listened to in this narrative theology must be stories considered to be healing by other than the primary implementers. Ideally these stories would not just be talked about, but would be seen and visited by a panel of experienced community leaders. That panel would then reflect on the nature of the wounding, the kinds of healing interventions attempted, and the actual results. They would be able to reflect on principles of how biblical healing is seen in their communities. If the process of telling, seeing, and thinking is successful, then the biblical seed of shalom would both be enjoyed as a fruit as well as planted back into the fertile minds and lives of those leaders for continued implementation.

\section{A STUDY IN COMMUNITY HEALING}

This study on healing in community has been viewed through the prism of "shalom". Shalom occurs when people who are in a right relationship with God and each other enjoy and share together the resources of the earth in ways that show Christ is Lord of all creation. This is a community with shared values and communication (social); shared vision and sense of purpose (mental); caring, trust, respect and recognition (emotional); teamwork and participation (volitional); and incorporation of diversity (physical) (characteristics from Royal \& Rossi 1996:415, categories given by author). An agent of healing, then, is anything that promotes these characteristics in and among people who live together and know each other.

The vision of this study was to take community leaders into various situations, both present and past, where healing occurs and allow them to analyze what works and why. An obvious limitation is the impracticality of taking a panel of community leaders to diverse places over time. To overcome these limitations, nine stories of community healing have been told in video form and analyzed in this study. (Everyone who wishes may both see the stories themselves and evaluate them, available on CD Rom from the Institute for the Study of African Realities, Box 24686 Nairobi, 00502 Kenya).

The evaluators were twenty nine men and twelve women from twelve different African countries, representing many different denominations, including Anglican, Presbyterian, Methodist, Baptist, Pentecostal, 
and various independent church traditions. On a scale of 1 to 12 , which factored in both the number of years of church experience, and the kinds of experience (pastoring, NGO work etc), both the median and the mean experience level of these leaders was 10 . On a scale of 1 to 10 measuring their families (numbers and ages of children), the mean score was 8.5. To have scored above an 8 required the leader-observer to have more than three children who were ten years of age or more. Most of the participants had cared for their own hurting children in a war zone and had at least 8 years experience in ministry. A basic assumption of this study was that these men and women had the ability to judge the quality of healing if they judged it from their own worldview. These participant-viewers met in four different focus groups (two in South Africa, one in Rwanda and one in Kenya) to view each of the story-films twice. After viewing them they were given the opportunity to both record their own thoughts and to interact with each other. Following is a description of what they saw, and then how they interpreted what they saw.

\section{NINE STORIES OF HEALING IN COMMUNITY}

The only non-African film, Martin Luther King (MLK), shows the story of a people movement that brought about changes in legislation of one of the world's most powerful nations. The simple yet motivating speeches of Martin Luther King cut through generations of blacks who felt that they were inferior to whites in nearly every respect. The social movement began chiefly because of the Southern Christian Leadership Conference - a gathering of Southern Black preachers, who believed that the Bible addressed social world issues. Perhaps the most important thing noted from this story was that individual and collective pride or sense of worth is a fundamental ingredient to building a community. Though the non-violent activist strategies did bring a change in laws, it produced in people intentional self-reflection and self-realization that became self-actualization. Unfortunately it did not bring wide-spread racial harmony and reconciliation. The collective action combined with powerfully motivating teaching and preaching, did indeed produce a kind of healing. For many viewers this was the most informative story they watched.

The second story took a deeper look at what happens in smaller groups as people begin to talk together and share their pains. The story of the Khulamani support groups in South Africa describes people who suffered gross injustices and had no voice to object. The Khulamani 
support groups started simply as a community response embracing those who had lost family members in a government system that would give no answers when family members simply disappeared. The support group appears to be an excellent intervention that brings healing in several ways, but it needs to be accompanied by teaching or facilitation that is able to replace the negative and hurting emotional, social and volitional elements with a healing, helpful direction.

The third story, St James Massacre, again from South Africa, shows the healing interventions that are able to bring about forgiveness and reconciliation after intense pain. Following a terrorist strike in the midst of a church service, this congregation of the Church of England of South Africa embarked on a continued ministry of teaching, counseling and ministering to its people. They provided both formal and informal support groups, and counseling was done. Like the other South African stories there was a healing in the release of negative emotions, in confession and forgiveness, and in an increased sense of understanding and inclusiveness. People not only felt closer to others in the church, but felt closer to others who suffered, who had been treated unjustly.

The fourth story, Video Dialogue, is the story of two embattled communities outside Johannesburg where, through a video camera, people were able to see each other as humans who were in the process of heaping misery upon each other. Each side was enabled to see that the wounding they received was very similar to the wounding they were delivering. Such understanding was a healing through self-reflection. With the presence of a facilitator/mediator these hard and intense feelings were redirected toward finding the "human" in the enemy, and identifying new ways of interacting. The video dialogue was moved into an actual forum of face-toface discussions that used ceremony to bless what was accomplished and focus on the healing that remained.

Three stories of healing were from Rwanda and Burundi. The killing that took place in Rwanda in 1994 may have been five times higher in the first six weeks than the daily killing rate of the Nazi death camps (Relph 1998:133). The story of the Africa Revival Ministry and the Living Church evidences that local church ministries may bring significant healing to many. Maternity and general clinics, mental health facility, schools of many kinds and levels, agriculture projects, vocational training, orphanages etc. were all specific ways in which orphans, widows, disabled 
and traumatized people were offered healing care. Although full ethnic "balance" was not achieved, the ministry did seek to be inclusive rather than exclusive. This operative goal seems to have been a significant reason why these project-style interventions produced so much healing. The founder of the ARM, David Ndaruhutse, was an evangelist who believed in uncommon workings of God, but his greatest joy was the reconciliation he had witnessed (Relph 1998:14).

The sixth story is the story of healing a geographic community in Bujumbura, Burundi by rebuilding houses. The Youth in Construction in a World of Destruction (JRMD) ministry had a very tenuous connection with churches in Bujumbura, but sought to link their home-building project with congregations in Nairobi and in the USA, using a "global body of Christ that extends a hand of help" idea. The story of JRMD indicates that the healing ingredient was the idea of working together, mobilizing people to collaborate.

The seventh story of the African Evangelistic Enterprise (AEE) trauma healing workshops brought a deeper look at the healing which symbolism can bring. Since the AEE team's interventions were primarily workshops that gave people opportunity to talk together and to engage in symbolic activities, identification with other ethnicities was symbolic, but restitution was individual, personal, and real. This individual change enabled the sense of identification with others who had experienced the release of pain and anger to be real and communal rather than only symbolic and individual.

Our eighth story is set in Kenya and tells the healing of individuals who were wounded in the US embassy bombing. They were the survivors who needed emotional and physical healing. The wounded included families whose main support was the person who was killed or lost their sight in the blast. The Beyond the Disaster ministry was a three-month trauma counseling intervention that sought to bring healing to posttraumatic stress. This ministry worked through local congregations and the mobilization of over 200 volunteer counselors.

The last story is also set in Kenya, in the small commutercommunity of Kiambu outside Nairobi. The story of Transformations states that to the decayed center where crime, prostitution, and alcohol abounded but where no churches could grow, came a complete social change. It was rags to riches, booze to beauty, and evil to good. It tells 
about a single pastor's foray into the socially broken town of Kiambu. "Spiritual warfare" was the single intervention, and total community transformation is claimed. The primary question this film raises is whether or not it is true, as some may believe, that the force of this healing is simply in the verbalization of the name "Jesus" (Weatherhead 1951:89). Such verbalization is sometimes dubbed as "spiritual warfare". This film was a type of "control" in the study, it was not filmed by the author but shown uncut with all of its claims.

There can be healing even if there is not transformation. The elements of the healing are the same whether on a small or a large scale, whether deep or shallow. What emerges when we relate these various healing stories together is that the combination of interventions produces a far greater impact than the simple existence of a given intervention. Healing is best promoted through the synergistic result of multiple interventions. Listening to the observations made about these stories, brings us the following conclusions:

\subsection{Indicators of healing}

Let us return to the mango tree. Understanding why some seeds grow and some do not tell us the best kind of seeds for planting. The lessons must be used in some systematic way to assist in the creation of a grove of mango trees. Furthermore, when a seed is first planted there are early indicators of growth so that the attending farmer will know how to spot a mal-formed tree or some form of rust and rot that will keep the good seed from growing to bear a bountiful harvest. Indicators of mango tree growth are like indicators of healing in community.

The following chart shows key indicators found in the nine stories told and analyzed and are listed in the category of their primary evidence. This list is far from complete. Additional indicators could be added by observing the results of other intervention programmes. 
Table 1 Indicators of Healing

\begin{tabular}{|c|c|c|c|c|}
\hline Emotional & Social & Volitional & Physical & Mental \\
\hline $\begin{array}{l}* \text { Release } \\
\text { negative } \\
\text { emotion }\end{array}$ & $\begin{array}{l}* \text { Restore } \\
\text { relationship }\end{array}$ & $\begin{array}{l}* \text { Giving and } \\
\text { receiving for- } \\
\text { giveness }\end{array}$ & $\begin{array}{l}* \text { Restitu- } \\
\text { tion }\end{array}$ & $\begin{array}{l}\text { * Increased } \\
\text { understan- } \\
\text { ding }\end{array}$ \\
\hline $\begin{array}{l}\text { * Show } \\
\text { emotional } \\
\text { change }\end{array}$ & $\begin{array}{l}\text { * Represent } \\
\text { others in } \\
\text { repentence }\end{array}$ & $\begin{array}{l}\text { * Spiritual } \\
\text { renewal }\end{array}$ & $\begin{array}{l}\text { * Freedom } \\
\text { of move- } \\
\text { ment }\end{array}$ & $\begin{array}{l}* \text { Hope for } \\
\text { future }\end{array}$ \\
\hline * Comfort, joy & * Inclusiveness & $\begin{array}{l}* \text { Confession, } \\
\text { admitting } \\
\text { wrong }\end{array}$ & $\begin{array}{l}* \text { Collabo- } \\
\text { ration in } \\
\text { projects }\end{array}$ & $\begin{array}{l}* \text { Self- } \\
\text { reflection }\end{array}$ \\
\hline $\begin{array}{l}\text { * Trust others } \\
\text { with own } \\
\text { emotions }\end{array}$ & $\begin{array}{l}* \text { Connection } \\
\text { with indivi- } \\
\text { duals or groups }\end{array}$ & $\begin{array}{l}* \text { Other- } \\
\text { focused }\end{array}$ & $\begin{array}{l}* \text { Physical } \\
\text { needs met }\end{array}$ & $\begin{array}{l}\text { * Planning } \\
\text { for change }\end{array}$ \\
\hline $\begin{array}{l}* \text { Bear others' } \\
\text { burdens }\end{array}$ & * Leadership & $\begin{array}{l}* \text { Acceptance } \\
\text { of pain, loss }\end{array}$ & * Security & \\
\hline \multirow[t]{6}{*}{$\begin{array}{l}* \text { Empathetic } \\
\text { listening }\end{array}$} & $\begin{array}{l}\text { * Overcome } \\
\text { social barrier }\end{array}$ & $\begin{array}{l}* \text { Repentan- } \\
\text { ce, sorrow for } \\
\text { wrong }\end{array}$ & & \\
\hline & * Listen, talk & & & \\
\hline & $\begin{array}{l}* \text { Reconcilia- } \\
\text { tion }\end{array}$ & & & \\
\hline & $\begin{array}{l}\text { Churches } \\
\text { planted }\end{array}$ & & & \\
\hline & $\begin{array}{l}\text { Small groups } \\
\text { formed }\end{array}$ & & & \\
\hline & $\begin{array}{l}* \text { Service to } \\
\text { another }\end{array}$ & & & \\
\hline
\end{tabular}

\section{USING INDICATORS TO CREATE PROGRAMMES}

Creating programmes of intervention is sometimes a hit-or-miss intuitive idea about what will help a situation. Better intuitive ideas may come following a time of prayer and reflection, but as was seen in the Transformations story, prayer and fasting may still not create programme interventions that are aimed at change. What else might the programme planner/church planter have done in Kiambu? First, had he really known his community through visitation with residents, shopkeepers, police, town 
leaders etc, as well as in prayer, then he would have known many of the needs of the community. He might have started with a grid like this one that was identified by the focus groups viewing the film.

\section{Table 2: Indicators of Need}

\begin{tabular}{|l|l|l|l|l|}
\hline Emotional & Social & Volitional & Physical & Mental \\
\hline Fear & Drunkenness & $\begin{array}{l}\text { Follow } \\
\text { Satan's ways }\end{array}$ & $\begin{array}{l}\text { No secu- } \\
\text { rity at } \\
\text { night }\end{array}$ & Not know Bible \\
\hline mind & $\begin{array}{l}\text { Concern for } \\
\text { others }\end{array}$ & Determination & $\begin{array}{l}\text { Churches } \\
\text { that don't } \\
\text { grow }\end{array}$ & $\begin{array}{l}\text { ID spiritual } \\
\text { oppression }\end{array}$ \\
\hline Hope & $\begin{array}{l}\text { Street } \\
\text { children }\end{array}$ & Integrity & Poverty & $\begin{array}{l}\text { Knowledge of } \\
\text { God }\end{array}$ \\
\hline Witchcraft & Prostitution & Salvation & $\begin{array}{l}\text { No deve- } \\
\text { lopment }\end{array}$ & Spiritual nurture \\
\hline Courage & & Crime & ID root causes \\
\hline $\begin{array}{l}\text { Acceptance, } \\
\text { self worth }\end{array}$ & & & Drugs & $\begin{array}{l}\text { How to deal with } \\
\text { root causes }\end{array}$ \\
\hline Salvation & & & & \\
\hline
\end{tabular}

With at least this much understanding of the needs of Kiambu, the church planter might use a table of interventions to decide which interventions would best deal with the needs. In selecting various interventions for Kiambu, the church planter would do well to select those interventions that involve more than one aspect of holism, or make the intervention to actually be a combination of interventions. For example, a street children ministry should include business people and town leaders, it could provide some basic education as well as food and shelter, it should connect the children with families in some way, and give the children the opportunity to express their own pain and find new identity in Christ. It could mobilize the youth of various churches to assist in a recreation program, or put street children to helping mobilized youth in cleaning the streets of the town.

Biblical "answers" to human needs must address specific questions rather than a vague sense of "spiritual". A key success in the stories filmed 
was the ability to identify the needs, and a way of responding that fit the abilities, resources, and inspiration of the project initiators.

\subsection{Using indicators for programme evaluation}

Holistic interventions and indicators of brokenness or healing are useful for creating ministry programmes as well as in evaluating those programmes. One evaluation tool is a simple chart that lists who is impacted, and the outcomes. Both should come from the programme plan, and should reflect the various aspects of holism. During an AEE selfevaluation of their healing workshops, a number of indicators were identified in community healing. If they are placed in a holistic grid form, it looks like this:

\section{Table 3 Programme Evaluation Indicators of Healing}

\begin{tabular}{|l|l|l|l|l|l|l|}
\hline & Pastors & $\begin{array}{l}\text { Church } \\
\text { leaders }\end{array}$ & $\begin{array}{l}\text { Church } \\
\text { mem- } \\
\text { bers }\end{array}$ & Youth & $\begin{array}{l}\text { Chil- } \\
\text { dren }\end{array}$ & $\begin{array}{l}\text { Non- } \\
\text { mem- } \\
\text { bers }\end{array}$ \\
\hline Emotional & & & & & & \\
\hline Releases own anger, revenge & & & & & & \\
\hline Seeks to understand needs of others & & & & & & \\
\hline Expresses positive emotion to other group & & & & & & \\
\hline Shows positive emotions towards others & & & & & & \\
\hline Uses emotionally healing language about \\
other group
\end{tabular}




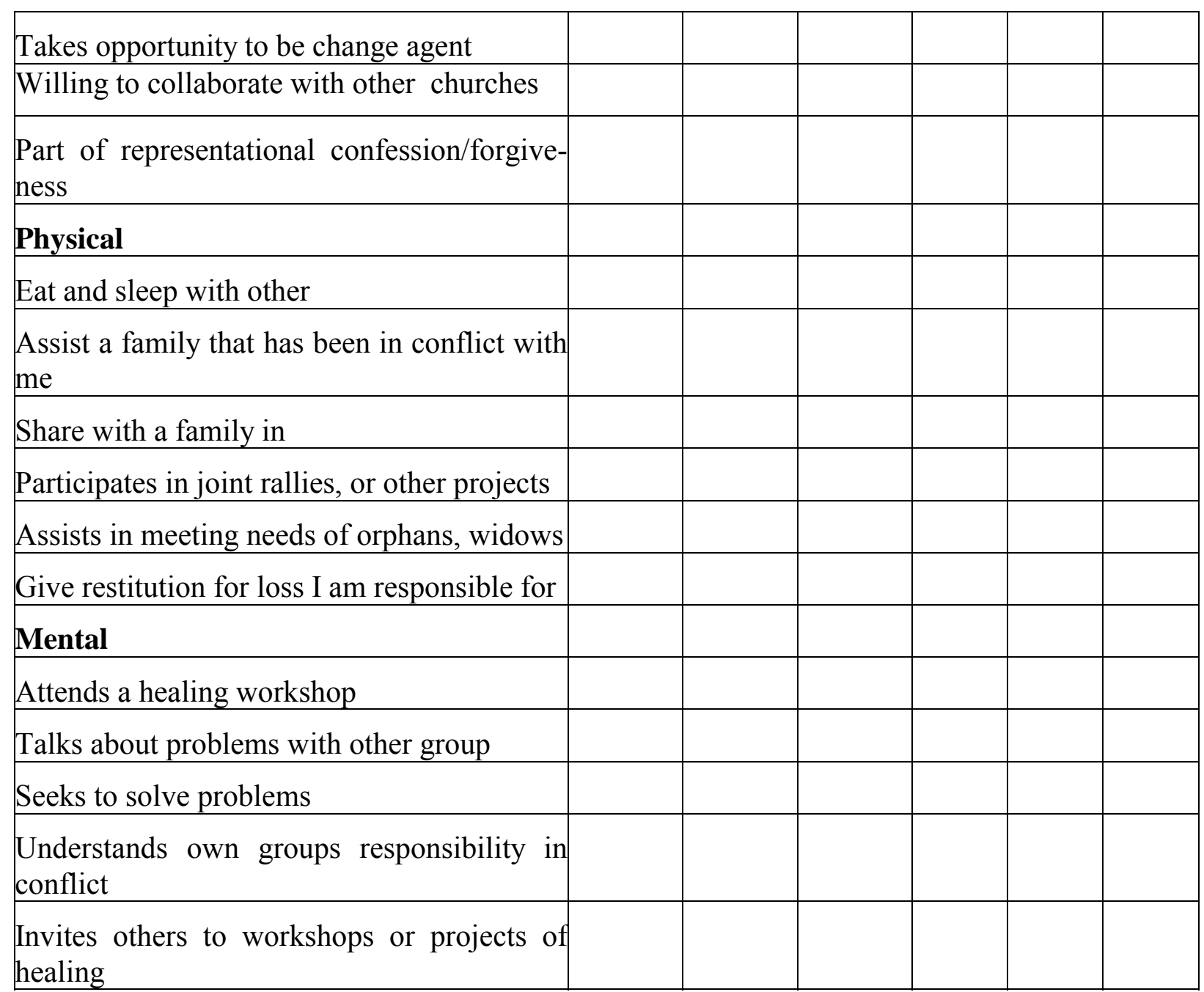

(Sabamungu and Dortzbach 1999)

The evaluation grid is then used for both pre-workshop and post-workshop evaluation, when facilitators and/or participants place a mark in each cell that applies. In such a manner a density chart can be created that reveals where a community may be in its process of healing. To better reveal where a community is in the process of healing, negative indicators could also be added. This would show when a community might possess destructive or broken elements. By utilizing more of the interventions from table 4 it would be possible to construct programmes for intervention or training that are richer in content and therefore more likely to produce healing.

Relief and development agencies often race each other to the scene of a disaster. As this research was being conducted the town of Goma on the eastern border of Congo was again the center of global attention. A lava flow scattered people westward and deeper into Congo or eastward 
into Rwanda. Of course, the lava flow is not violent conflict, but it covers a violent conflict. Its flow covered a large burial mound near the airport, nick-named "Clinton's Hill" by many local residents, who reflected on the thousands buried there in the 1994 cholera epidemic which followed the mass migration out of Rwanda's decimation. Little was done to even attempt to bring healing to the community then. The relief agencies now seek again to provide shelter and water and food - all physical needs and interventions. Some focus may come again to help families locate members who have become separated in the flight. But little focus will be given to the emotional trauma that again comes to the region. Africa Network News on the BBC may interview someone who mentions the likely re-entry of angry and bitter interahamwe militants who were able to move back into Rwanda under the cover of a fresh migration. But creating community-healing interventions was not a financial priority of the world at any time during the aid flow from 1994-1999 in the Goma region. Most agencies left, believing their task was done when the blue tents came down and people moved back into Rwanda. The silent river of lava will cover the remains of war and broken society. By March 2002 an estimated 2 million people have lost their lives in the DRC since 1998 from violent conflict, starvation and disease resulting from that conflict (www.nytimes. com/reuters/world/international-congo-democratic-talks.html). The silent scream asks us once more to answer the question, "Healed?"

\section{HEALING INTERVENTIONS OF THE CHURCH}

The chart on the next page summarizes in italics those interventions reported on in a wide variety of literature. Those interventions not italicized are ones identified by the church leaders in this study which they saw as appropriate healing interventions which came from the films they viewed.

\section{Table 4 Healing Interventions of the Church}

\section{EMOTIONAL SUPPORT}

Mourning; Hospitality; Presence; Scripture reading and Bible stories; Public opportunity for transparency, vulnerability; Counseling; Establish monuments and memorials; Group palaver; Blessing; Prayer; Story Telling; Empathetic listening; A support system; Language choice and use; Teaching and preaching; Faith celebrations; Promotion of articulated forgiveness; Promotion of articulated confession; Rebuking; Memorials; Worship, crusade; Singing; Service; Compassion; Trust building; Encouragement; Giving/Receiving Love; Tell own story of pain; Counseling. 


\section{SOCIAL SUPPORT}

Action groups; Networking and training; Discipleship groups; Creation and use of Liturgy; Creating social order through structure and leadership; Convening a community; Create active non-violent responses to evil; Create active non-violent responses to evil; Presence; Provide forums for diverse peoples to meet; Political, structural involvement; Representational repentance; Give community recognition; Theological education that prepare for reconciliation; Provide special worship/celebration programs; Create Church coalitions and co-operative efforts; Create support groups; Provide hospitality; Encourage and honor a vocation of healing; Create Memorials; Promotion of personal conflict resolution; Make suffering redemptive; Identify the impact on all actors; Promote social reconciliation; Speak and give public platforms for truth telling; Actively seek justice and work against injustices; Seek to transform conflicting relationships; Teaching and preaching that challenges evil; Identify and create inter-connected interventions; Monitor cultural practices that destroy wholeness; Identify and create covenants of peace; Inform the Christian community of suffering; Integrate fellowship and worship; Promote local congregational participation in peacemaking; Visitation; Worship; Counseling; Identification; Prayer; Broad -based; Care; Mobilization; Support group; Family; Talking together; Marches; Drama ; Work with other churches; Support Groups.

\section{VOLITIONAL CHANGE}

Celebrate gains in relationships; Celebrate gains in relationships; Develop kingdom ethics and values; Create and use teaching opportunities to help focus on reconciliation; Constantly push and encourage people to embrace differences; Encourage Christians to live in conscious awareness of their reconciliation with God; Look for individual and community needs that might be met; Provide trauma counseling and create trauma awareness; Promote public and private opportunities to speak truth about situations of conflict; Encourage public and private articulation of forgiveness; Discipleship must include listening and speaking to those in conflict with us; Create conflict when it forces structural justice and redemptive action; Provide opportunity and encourage people to take the opportunity to publicly confess corporate failure; Teach and make clear the choices which people have and are making; In receiving confessions, require that personal responsibility is accepted; Forgiveness; Confession; Reconciliation; Opportunity to be involved; Representational repentance; Drug rehabilitation project; Youth mobilizaton for a project; Volunteer opportunity in projects; Visit offenders in jail; Community plan for action.

\section{PHYSICAL SUPPORT}

Recognize that physical healing is a divine act and physical interventions may only be symbolic; Use physical symbols to be reminders of commitments made; Identify the correct time and kind of reparation to be made in reconciliation; Use art and beauty to restore a sense of humanity; Provide hospitality; Encourage humor, laughter and joy; Organize and encourage acts of kindness; Encourage appropriate touch in healing ceremonies; Advocate new ways of managing wealth and property ownership; Encourage and structure story-telling opportunities; Advocate and identify programs that might reduce violence; Encourage all Christians to identify how they connect with others in compassion; Restitution; Project done together; Micro-enterprise; Job placement; Medical clinic; Maternity clinic; Agriculture project; Street children project; Orphanage; Feeding program; House building project; Clothing distribution; Community meals, celebrations; Boycott; Meet needs of victims. 


\section{MENTAL GROWTH}

Teach and preach about the consequence of violence: Teach truth about health and wholeness; Teach and counsel people to understand the redemptiveness of hurt; Use the Biblical narrative to frame life's stories and show their place in God's greater story; Use a national event to grow a broad base to support, education and mobilization activities; Create a multi-faceted education and awareness campaign; Evaluate existing church programs on the basis of whether or not they are helping people to help themselves; Use conflict as a teaching moment; Provide opportunities for communities to express and listen to the pain that they feel in the protective buffering environment of the church; Be actively engaged in non-violent activities; Sponsor community memorial events; Be sure that confession is followed by appropriate restitution; Use Scripture to give God's thoughts about conflict, evil, and pain; Symbolic acts; Reflection (personal); Teaching/learning; Information, awareness raising; Nursery and elementary school; Public lectures; Workshops; Training for church leaders; Vocational school.

\section{Consulted literature}

Alexander, T D and Rosner, F eds. 2000. The History of Biblical Theology. New Dictionary of Biblical Theology. Downers Grove: Intervarsity.

Batchelor, P 1993. People in Rural Development, 2nd rev. ed. Carlisle: Paternoster Press.

Daily Nation, 2002. Nation Group Newspapers. Nairobi. Feb 10.

Delumeau, J 1998. Religion, Misfortune and Illness in the Pre-industrial West, Concilium. 5, 33-48

Dortzbach, K 2002. Wholeness and Healing. Video Series on CD. Institute for the Study of African Realities:Nairobi

Ewart, M \& Pocock, M 1984. New Directions and Opportunities for Christian Health Care Ministries. Wheaton: MAP International.

Healey, J and Donald Sybertz, D 1996. Towards an African Narrative Theology. Nairobi: Paulines Publications African.

Kocha (sa). Monthly brochure. Nairobi: Community Peace Museums Programme.

Kraybill, D 1990. The Upside-Down Kingdom, 2nd ed, Scottsdale: Herald Press.

MacDonald, M 1982. Religion, Social Change and psychological healing in England 1600-1800. In Shields, The Church and Healing. Oxford: Ecclesiastical History Society, 101-126.

Rack, H 1982. Doctors, Demons and Early Methodist Healing. In Shields, The Church and Healing. Oxford: Ecclesiastical History Society, 137-152.

Relph, P 1998. An African Apostle. Kent: International Media for Ministry. 
Reuters, 2002. Africa Congo Talks End Without Withdrawal Timeframe, New York Times, nytimes.com/reuters/world/international-congo-democratic-talks.html, downloaded April 3, 2002.

Royal, M A \& Rossi, R J 1996. Individual-Level Correlates of Sense of Community: Findings from Workplace and School. Journal of Community Psychology 24, 395416.

Sabamungu, A \& Dortzbach, K 1999. Indicators of Healing, AEE Healing Program Evaluation. Institute for the Study of African Realities, unpublished programme evaluation submitted to AEE leadership, 1999.

Sentinel Group, About Sentinel, Transformations, Resources, Sentinel Group, http:// sentinelgroup. org/pressrelease.html, 2001-29-12.

Steward, J 1994. Biblical Holism: Where God, People and Deeds Connect, an interactive Workshop, Burwood: World Vision Australia.

Strong 1995. Enhanced Strong's Lexicon. Oak Harbor: Logos Research Systems.

Thomas, K 1971. Religion and the decline of magic. London: Weidenfeld and Nicolson.

Weatherhead, L D 1971. Psychology, Religion and Healing. Warwick Square: Hodder and Stoughton. 